\title{
Improving the Level and Consistency of Glyphosate-Resistant Canada Fleabane (Erigeron canadensis L.) Control With Bromoxynil-Based Tankmixes Applied Preplant to Soybean
}

\author{
Meghan Dilliott ${ }^{1}$, Nader Soltani ${ }^{1}$, Darren E. Robinson ${ }^{1}$, David C. Hooker ${ }^{1} \&$ Peter H. Sikkema ${ }^{1}$ \\ ${ }^{1}$ Department of Plant Agriculture, University of Guelph, Ridgetown, ON, Canada \\ Correspondence: Nader Soltani, Department of Plant Agriculture, University of Guelph, 120 Main St. East, \\ Ridgetown, ON, N0P 2C0, Canada. E-mail: soltanin@uoguelph.ca
}

Received: November 4, 2021

Accepted: November 27, 2021

Online Published: December 15, 2021

doi:10.5539/jas.v14n1p11

URL: https://doi.org/10.5539/jas.v14n1p11

\begin{abstract}
Glyphosate-resistant (GR) Canada fleabane (Erigeron canadensis L.) is a problematic weed in soybean. Bromoxynil-based tankmixes provide control of GR Canada fleabane in monocot crops; however, there is limited research on preplant (PP) applications in soybean. The objective of this study was to determine the best third tankmix partner with glyphosate plus bromoxynil applied PP to improve the level and consistency of GR Canada fleabane control in soybean. Four field trials were conducted over a two-year $(2020,2021)$ period. Glyphosate plus bromoxynil controlled GR Canada fleabane 52,58, and $69 \%$ at 2, 4, and 8 weeks after application (WAA) respectively. The addition of saflufenacil to glyphosate plus bromoxynil improved GR Canada fleabane control $39 \%$ at 2 WAA and the addition of dicamba to glyphosate plus bromoxynil improved GR Canada fleabane control 39 and $29 \%$ at 4 and 8 WAA, respectively. The addition of bromoxynil to glyphosate plus 2,4-D ester or dicamba improved GR Canada fleabane control by 36 and 35\%, respectively, at 2 WAA. The addition of bromoxynil to glyphosate plus tiafenacil or pyraflufen-ethyl/2,4-D improved GR Canada fleabane control by $19 \%$ at 8 WAA. The addition of bromoxynil to glyphosate plus metribuzin improved GR Canada fleabane control 31, 32, and 36\% at 2, 4, and 8 WAA, respectively. Antagonism was observed between bromoxynil plus glyphosate plus tiafenacil or halauxifen-methyl 8 WAA, while the interaction between bromoxynil plus glyphosate plus pyraflufen-ethyl/2,4-D was considered synergistic. The addition of metribuzin, tiafenacil, pyraflufen-ethyl/2,4-D, 2,4-D ester, halauxifen-methyl, saflufenacil or dicamba to glyphosate plus bromoxynil improved the consistency of GR Canada fleabane at 2, 4, and 8 WAA. This study concludes that the addition of saflufenacil or dicamba to glyphosate plus bromoxynil can improve the level and consistency of GR Canada fleabane control applied PP to soybean.
\end{abstract}

Keywords: additive, antagonistic, biomass, density, horseweed, synergy, weed control, grain yield

\section{Introduction}

Glyphosate-resistant (GR) Canada fleabane was the first documented dicot weed to evolve resistance to glyphosate (Heap, 2020; VanGessel, 2001). GR Canada fleabane can produce thousands of seeds (Bhowmik \& Bekech, 1993; Davis et al., 2009) which can move up to $500 \mathrm{~km}$ in one dispersal event (Shields et al., 2006). In Ontario, GR Canada fleabane primarily emerges in the spring and in the fall; though, if temperature and soil moisture conditions are favourable, it has been reported to emerge every month of the year except January (Cici \& Van Acker, 2009; Main et al., 2006). Seeds within the top $0.3 \mathrm{~cm}$ of the soil surface can be stimulated by light and have the greatest likelihood of germinating and emerging (Nandula et al., 2006); though, its ruderal nature allows it to germinate in a variety of landscapes (Weaver, 2001). GR Canada fleabane has been confirmed in 14 countries as of 2020 (Heap, 2020).

GR Canada fleabane interference can reduce soybean yield. GR Canada fleabane interference can result in up to 93\% yield loss if no weed management strategies are used (Byker et al., 2013a). In most soybean systems, GR Canada fleabane should be managed before soybean emergence to prevent yield loss (Bruce \& Kells, 1990). In conventional-tillage production systems, tillage can be used to manage GR Canada fleabane, but in no-tillage systems, herbicides must be used to manage GR Canada fleabane (Bruce \& Kells, 1990). Postemergence (POST) 
herbicides provide minimal control of GR Canada fleabane in GR and non-GMO soybean (Byker et al., 2013b); therefore, preplant (PP) and preemergence (PRE) herbicides must be used for acceptable control.

Bromoxynil is a photosystem II (PSII)-inhibiting herbicide (Fedtke \& Duke, 2005; Shaner, 2014). Bromoxynil is a contact herbicide (Bayer CropScience Inc., 2019) that can outcompete plastiquinone at the $\mathrm{Q}_{B}$-binding site on the D1 protein, which inhibits electron transport, uncouples oxidative phosphorylation, and results in the reactive oxygen species formation and lipid peroxidation (Shaner, 2014; United States Environmental Protection Agency, 1998). Bromoxynil applied POST is not registered for use in soybean since it can cause leaf necrosis and stunting, though the plant may recover with little effect on yield (Andersen et al., 1973; Wax et al., 1974). Bromoxynil is registered to control select annual broadleaf weeds in corn, small grains, alfalfa, carrot, garlic, and onion (Boydston \& Al-Khatib, 1993; Bayer CropScience Inc., 2019). Bromoxynil is a contact herbicide that is generally used to control annual broadleaf weeds in monocot crops.

GR Canada fleabane is currently not listed as one of the weeds controlled on the brmoxynil label, but prior research with bromoxynil-based tankmixes in corn and winter wheat has demonstrated GR Canada fleabane control. Mahoney et al. (2017) and Metzger et al. (2019) observed 93 and 94\% control, respectively of GR and multiple-herbicide-resistant (MHR) Canada fleabane with bromoxynil $\left(280 \mathrm{~g}\right.$ ai ha $\left.{ }^{-1}\right)$ plus atrazine $\left(1500 \mathrm{~g} \mathrm{ai} \mathrm{ha}^{-1}\right)$ applied POST in corn 8 WAA. Quinn et al. (2021) reported 98\% GR Canada fleabane control with a premix of pyrasulfotole/bromoxynil $\left(205 \mathrm{~g}_{\text {ai ha }}{ }^{-1}\right)$ plus AMS $\left(1 \mathrm{~L} \mathrm{ha}^{-1}\right)$ applied POST in winter wheat $8 \mathrm{WAA}$. Mahoney et al. (2016) observed bromoxynil (174 $\mathrm{g}$ ai ha $\left.{ }^{-1}\right)$ plus pyrasulfotole $\left(31 \mathrm{~g} \mathrm{ai} \mathrm{ha}^{-1}\right)$ applied POST controlled $97 \%$ of GR Canada fleabane in winter wheat at 8 WAA. Bromoxynil tankmixes control GR Canada fleabane in monocot crops, which suggests potential for preplant (PP) applications in soybean.

Based on the aforementioned research, Westerveld et al. (2021a) evaluated the GR Canada fleabane control with bromoxynil, metribuzin, and bromoxynil plus metribuzin applied PP in soybean. Bromoxynil $(35,70,140,280$, $560,1120 \mathrm{~g}$ ai ha $\left.{ }^{-1}\right)$ provided 31 to $96 \%$ control, metribuzin $\left(400 \mathrm{~g}\right.$ ai ha $\left.{ }^{-1}\right)$ provided $80 \%$ control and the combination of bromoxynil plus metribuzin increased GR Canada fleabane control to 89 to $100 \%$ at 8 WAA; similar to current industry standards of glyphosate plus saflufenacil $\left(25 \mathrm{~g}\right.$ ai ha $\left.{ }^{-1}\right)$ plus metribuzin $\left(400 \mathrm{~g}\right.$ ai ha $\left.{ }^{-1}\right)$ (Budd et al., 2016) and glyphosate/dicamba (1800 $\left.\mathrm{g} \mathrm{ae} \mathrm{ha}^{-1}\right)$ plus saflufenacil (25 $\mathrm{g}$ ai ha $\left.{ }^{-1}\right)$ (Hedges et al., 2018). Therefore, more research is required to investigate possible tankmix partners with bromoxynil for GR Canada fleabane control applied PP in soybean. It is hypothesized the addition of metribuzin, tiafenacil, pyraflufen-ethyl/2,4-D, 2,4-D ester, halauxifen-methyl, saflufenacil or dicamba to glyphosate plus bromoxynil applied PP will improve the level and consistency of GR Canada fleabane control in soybean.

\section{Materials and Methods}

\subsection{Experimental Methods}

Four field experiments were conducted over a two-year period $(2020,2021)$ at sites with confirmed GR Canada fleabane in southwestern Ontario. A $2 \times 8$ factorial was organized in a randomized complete block design (RCBD) with 4 replications. Factor One was a control and bromoxynil, and Factor Two was a control, metribuzin, tiafenacil, pyraflufen-ethyl/2,4-D, 2,4-D ester, halauxifen-methyl, saflufenacil, and dicamba. The plots were $2.25 \mathrm{~m}$ [3 glyphosate/dicamba-resistant (GDR) soybean rows at $0.75 \mathrm{~m}$ apart] by $8 \mathrm{~m}$. The replicates were divided by a $2.0 \mathrm{~m}$ alley.

Herbicide treatments were made PP when majority of the Canada fleabane was $10 \mathrm{~cm}$ in height. Glyphosate (900 $\mathrm{g}$ ae ha ${ }^{-1}$ ) was added to each herbicide treatment applied PP. A CO CO $_{2}$-pressurized backpack sprayer was calibrated to dispense $200 \mathrm{~L} \mathrm{ha}^{-1}$ at $240 \mathrm{kPa}$. The sprayer had four, ULD 120-02 nozzles separated $50 \mathrm{~cm}$ apart. The spray width measured $2.0 \mathrm{~m}$. Following PP herbicide applications, a GDR soybean cultivar (DKB12-16) was seeded to about 400,000 seeds ha $^{-1}$ at a $3.75 \mathrm{~cm}$ depth. A glyphosate $\left(450 \mathrm{~g} \mathrm{ae} \mathrm{ha}^{-1}\right)$ cover spray was applied POST to eliminate the effects of other weed species and glyphosate-susceptible Canada fleabane. Site, year, location, soil, and agronomic details are listed in Table 1. Information pertaining to Canada fleabane including height and density at application and the resistance profile of the populations is presented in Table 2. The herbicide treatments that were used in this study are described in Table 3. 
Table 1. Site, year, location, soil characteristics, soybean seeding and soybean emergence dates for four trials conducted on commercial farms in southwestern Ontario, Canada in 2020 and 2021

\begin{tabular}{|c|c|c|c|c|c|c|c|c|c|c|c|}
\hline \multirow[b]{2}{*}{ Site } & \multirow[b]{2}{*}{ Year } & \multirow[b]{2}{*}{ Location } & \multicolumn{6}{|c|}{ Soil traits } & \multicolumn{3}{|c|}{ Agronomic information } \\
\hline & & & Texture & Sand & Silt & Clay & $\mathrm{OM}^{\mathrm{a}}$ & $\mathrm{pH}$ & $\begin{array}{l}\text { Treatment } \\
\text { spray date }\end{array}$ & $\begin{array}{l}\text { Soybean } \\
\text { seeding date }\end{array}$ & $\begin{array}{l}\text { Soybean } \\
\text { emergence date }\end{array}$ \\
\hline & & & & $\%$ & $\%$ & $\%$ & $\%$ & & & & \\
\hline S1 & 2020 & Ridgetown & Sandy loam & 75 & 17 & 7 & 1.9 & 7.1 & 26 May & 5 June & 11 June \\
\hline S2 & 2020 & Zone Centre & Loamy sand & 85 & 9 & 5 & 2.9 & 6.5 & 17 June & 24 June & 3 July \\
\hline $\mathrm{S} 3$ & 2021 & Kintyre & Sandy loam & 53 & 29 & 18 & 4.4 & 6.9 & 19 May & 19 May & 25 May \\
\hline S4 & 2021 & Bothwell & Loamy sand & 85 & 11 & 4 & 3.3 & 6.8 & 24 May & 12 June & 18 June \\
\hline
\end{tabular}

Note. ${ }^{\text {a }}$ Abbreviations: OM, organic matter.

Table 2. Canada fleabane height and density at time of application and resistance profile for trials conducted on commercial farms in southwestern Ontario, Canada in 2020 and 2021

\begin{tabular}{|c|c|c|c|c|c|c|}
\hline \multirow{2}{*}{ Site } & \multirow{2}{*}{ Year } & \multirow{2}{*}{ Location } & \multicolumn{2}{|c|}{ Canada fleabane } & \multicolumn{2}{|c|}{ Resistance } \\
\hline & & & Height & Density & Glyphosate & Cloransulam-methyl \\
\hline & & & $\mathrm{cm}$ & $\mathrm{m}^{-2}$ & $\%$ & $\%$ \\
\hline S1 & 2020 & Ridgetown & 7 & 492 & 100 & 99 \\
\hline $\mathrm{S} 2$ & 2020 & Zone Centre & 11 & 70 & 79 & 100 \\
\hline S3 & 2021 & Kintyre & 9 & 34 & 98 & 85 \\
\hline S4 & 2021 & Bothwell & 8 & 82 & - & - \\
\hline
\end{tabular}

Table 3. Herbicides used in four field trials in southwestern Ontario, Canada in 2020 and 2021

\begin{tabular}{|c|c|c|}
\hline Active ingredient & Trade name & Manufacturer \\
\hline Bromoxynil & Pardner® & Bayer CropScience Inc., 160 Quarry Park Blvd S. E., Calgary, AB. \\
\hline Metribuzin & Sencor ${ }^{\circledR}$ 480SC & Bayer CropScience Inc., 160 Quarry Park Blvd S. E., Calgary, AB. \\
\hline Tiafenacil $^{\mathrm{a}}$ & Terrad'or ${ }^{\mathrm{TM}}$ & ISK Biosciences., 7470 Auburn Rd, Painesville, OH 44077, United States. \\
\hline Pyraflufen-ethyl/2,4-D & Blackhawk & Nufarm Canada., 5101, 333-96 ${ }^{\text {th }}$ Ave N.E., Calgary, AB. \\
\hline 2,4-D ester & Ester 700 & Nufarm Canada., 5101, 333-96 ${ }^{\text {th }}$ Ave N.E., Calgary, AB. \\
\hline Halauxifen-methyl $^{\mathrm{a}}$ & Elevore & Dow AgroSciences Canada Inc., 2400, 215-2ns Street S. W., Calgary, AB. \\
\hline Saflufenacil $^{\mathrm{b}}$ & Eragon ${ }^{\circledR} \mathrm{LQ}$ & BASF Canada Inc., 100 Milverton Drive, Mississauga, ON. \\
\hline Dicamba & Xtendimax $^{\mathrm{TM}}$ & Bayer CropScience Inc., 160 Quarry Park Blvd S. E., Calgary, AB. \\
\hline
\end{tabular}

Note. ${ }^{a}$ MSO was add to all treatments with halauxifen-methyl $(1.0 \% \mathrm{v} / \mathrm{v})$ or tiafenacil $(0.5 \% \mathrm{v} / \mathrm{v}) .{ }^{\mathrm{b}}$ Merge $(1 \mathrm{~L}$ $\mathrm{ha}^{-1}$ ) was added to treatments with saflufenacil.

Canada fleabane control was assessed as a visual estimate of the reduction in Canada fleabane biomass using a 0 to 100 scale at 2, 4, and 8 weeks after application (WAA). A visual rating of 0 suggested no GR Canada fleabane control and a visual rating of 100 suggested plant death (Canadian Weed Science Society, 2018). Canada fleabane density and biomass were collected 8 WAA. Density was collected by counting Canada fleabane plants in two, $0.25 \mathrm{~m}^{2}$ quadrats placed randomly in the front and back of each plot. Biomass was collected by cutting the Canada fleabane where the stem meets the soil surface within each quadrat, placing the samples in separate bags for each individual plot, drying the samples to a constant moisture, and then weighing the samples.

A 0 to 100 scale was used to assess visible GDR soybean injury 2 and 4 weeks after soybean emergence (WAE); 0 suggested no soybean injury and 100 suggested soybean death (Canadian Weed Science Society, 2018). At soybean harvest maturity, two GDR soybean rows were harvested per plot using a small plot harvester. Soybean yield and moisture were recorded. Prior to analysis, the grain yield was corrected to a $13.5 \%$ moisture content.

\subsection{Statistical Analysis}

SAS 9.4 was the statistical software used in this study. The GLIMMIX procedure was used for the analysis. Herbicide treatment represented the fixed effect and block, block within location, and treatment by location represented the random effects. The Shapiro-Wilk test and the residual plots were utilized when assessing normality. Since no treatment by location interaction was found, the sites were pooled together for the analysis. An arcsine square root back transformation was used to meet normality assumptions for GR Canada fleabane 
control at 2, 4, and 8 WAA. Soybean yield data was assessed using the default link identity. A lognormal distribution using the link identity was used to assess GR Canada fleabane density and biomass; the omega procedure was used to back-transform the means from the analysis format (M. Edwards, Ontario Agricultural College Statistician, University of Guelph, personal communication). Mean separations were completed using the Tukey-Kramer's multiple range test $(\mathrm{p}<0.10)$. Significance was indicated by different letter codes within Table 4. To calculate the expected GR Canada fleabane control the Colby's equation was used. A: Bromoxynil and B: Tankmix partner.

$$
\text { Expected }=(\mathrm{A}+\mathrm{B})-\frac{\mathrm{A} \times \mathrm{B}}{100}
$$

The expected GR Canada fleabane biomass and density was calculated using a modified Colby's equation. The ' $\mathrm{W}$ ' in the equation represents the non-treated control mean.

$$
\text { Expected }=\frac{\mathrm{A} \times \mathrm{B}}{\mathrm{W}}
$$

A t-test was used to analyze the expected versus the observed values, significance was indicated when $\mathrm{p}<0.10$. The interactions were considered additive when the observed control value was the same as the expected control value. The interaction was considered synergistic or antagonistic when the observed control values were greater than or less than the expected control values, respectively (Colby, 1967). Conversely, if the observed density or biomass values were greater than or less than the expected density or biomass values then the interaction was considered antagonistic or synergistic, respectively (Colby, 1967). The coefficient of variation was calculated to ascertain the consistency of GR Canada fleabane control for each least square mean estimate.

\section{Results and Discussion}

\subsection{Soybean Injury}

Soybean injury was $\leq 10 \%$ at all sites across both years (data not presented).

\subsection{Glyphosate-Resistant Canada Fleabane Control}

The simple effects are presented in Table 4 since the interaction between Factor One (control and bromoxynil) and Factor Two (control, metribuzin, tiafenacil, pyraflufen-ethyl/2,4-D, 2,4-D ester, halauxifen-methyl, saflufenacil, and dicamba) for GR Canada fleabane control 2, 4, and 8 WAA was statistically significant (p < $0.10)$. 
Table 4. Glyphosate-resistant Canada fleabane control 2, 4, and 8 weeks after application (WAA), density, and biomass with bromoxynil-based tankmixes from four field trials conducted in southwestern Ontario, Canada in 2020 and 2021

\begin{tabular}{|c|c|c|c|}
\hline \multirow{2}{*}{ Bromoxynil } & \multicolumn{3}{|c|}{ Tankmix partners } \\
\hline & None & Bromoxynil & $\mathrm{SE}$ \\
\hline Weed control 2 WAA & \multicolumn{3}{|c|}{ 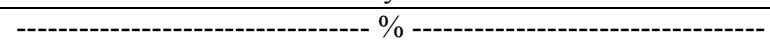 } \\
\hline None & $0 \mathrm{c} \mathrm{Y}$ & $52 \mathrm{~b} \mathrm{Z}$ & 7 \\
\hline Metribuzin & $43 \mathrm{~b} \mathrm{Y}$ & $62 \mathrm{ab} \mathrm{Z}(67)$ & 6 \\
\hline Tiafenacil $^{\mathrm{c}}$ & $60 \mathrm{ab} \mathrm{Z}$ & $60 \mathrm{ab} Z(70)^{*}$ & 7 \\
\hline Pyraflufen-ethyl/2,4-D & $58 \mathrm{ab} Z$ & $69 \mathrm{ab} \mathrm{Z}(74)^{* *}$ & 5 \\
\hline 2,4-D ester & $47 \mathrm{~b} \mathrm{Y}$ & $74 \mathrm{ab} Z(73)$ & 4 \\
\hline Halauxifen-methyl ${ }^{\mathrm{c}}$ & $58 \mathrm{ab} \mathrm{Z}$ & $71 \mathrm{ab} Z(78)^{*}$ & 4 \\
\hline Saflufenacil $^{\mathrm{b}}$ & 84 a Z & 85 a $Z(81)$ & 5 \\
\hline Dicamba & $52 \mathrm{~b} \mathrm{Y}$ & 80 ab Z (76) & 4 \\
\hline SE & 3 & 3 & \\
\hline \multicolumn{4}{|l|}{ Weed control 4 WAA } \\
\hline None & $0 \mathrm{c} \mathrm{Y}$ & 58 b Z & 7 \\
\hline Metribuzin & $45 \mathrm{~b} \mathrm{Y}$ & 66 ab Z (72) & 6 \\
\hline Tiafenacil $^{\mathrm{c}}$ & $50 \mathrm{ab} \mathrm{Z}$ & $62 \mathrm{ab} Z(71)$ & 7 \\
\hline Pyraflufen-ethyl/2,4-D & $66 \mathrm{ab} \mathrm{Z}$ & $78 \mathrm{ab} Z(82)^{* *}$ & 4 \\
\hline $2,4-\mathrm{D}$ ester & $77 \mathrm{ab} Z$ & 82 ab Z (87)* & 3 \\
\hline Halauxifen-methyl ${ }^{\mathrm{c}}$ & 87 a Z & 86 ab Z (93)* & 2 \\
\hline Saflufenacil $^{\mathrm{b}}$ & 87 a Z & 92 ab Z (87) & 3 \\
\hline Dicamba & 87 a Z & 95 a Z (94) & 2 \\
\hline SE & 3 & 2 & \\
\hline \multicolumn{4}{|l|}{ Weed control 8 WAA } \\
\hline None & $0 \mathrm{~d} Y$ & $69 \mathrm{~b} \mathrm{Z}$ & 7 \\
\hline Metribuzin & $46 \mathrm{c} \mathrm{Y}$ & $72 \mathrm{ab} Z(78)$ & 6 \\
\hline Tiafenacil $^{\mathrm{c}}$ & $51 \mathrm{bc} Y$ & 70 b Z $(76)^{*}$ & 7 \\
\hline Pyraflufen-ethyl/2,4-D & $68 \mathrm{abc} Y$ & $87 \mathrm{ab} Z(83)^{* *}$ & 4 \\
\hline 2,4-D ester & $84 \mathrm{ab} Z$ & 85 ab Z (90) & 7 \\
\hline Halauxifen-methyl $^{\mathrm{c}}$ & 89 a Z & 86 ab Z (93)* & 2 \\
\hline Saflufenacil ${ }^{\mathrm{b}}$ & 87 a Z & 95 ab Z (89) & 3 \\
\hline Dicamba & 94 a Z & 97 a Z (97) & 1 \\
\hline $\mathrm{SE}$ & 3 & 2 & \\
\hline Density & \multicolumn{3}{|c|}{ plants $\mathrm{m}^{2}$} \\
\hline None & $164 \mathrm{c} \mathrm{Y}$ & $30 \mathrm{ab} Z$ & 23 \\
\hline Metribuzin & $36 \mathrm{ab} \mathrm{Y}$ & $24 \mathrm{ab} \mathrm{Z}(46)^{*}$ & 8 \\
\hline Tiafenacil $^{\mathrm{c}}$ & $75 \mathrm{bc} \mathrm{Y}$ & 39 a Z (50) & 15 \\
\hline Pyraflufen-ethyl/2,4-D & $53 \mathrm{~b} Y$ & $21 \mathrm{ab} Z(51)^{* *}$ & 8 \\
\hline 2,4-D ester & $29 \mathrm{ab} \mathrm{Z}$ & $24 \mathrm{ab} Z(42)^{*}$ & 6 \\
\hline Halauxifen-methyl ${ }^{\mathrm{c}}$ & $20 \mathrm{ab} Z$ & 28 ab Z (43)* & 6 \\
\hline Saflufenacil $^{\mathrm{b}}$ & 17 a Z & 7 a $Z(38)^{* *}$ & 5 \\
\hline Dicamba & $25 \mathrm{ab} Z$ & $9 \mathrm{ab} Z(12)^{* *}$ & 4 \\
\hline SE & 7 & 4 & \\
\hline Biomass & \multicolumn{3}{|c|}{$\mathrm{g} \mathrm{m}^{-2}$} \\
\hline None & $154 \mathrm{~b} \mathrm{Y}$ & $88 \mathrm{~b} \mathrm{Z}$ & 20 \\
\hline Metribuzin & $151 \mathrm{~b} \mathrm{Y}$ & 123 b Z (62) & 28 \\
\hline Tiafenacil $^{\mathrm{c}}$ & $91 \mathrm{~b} \mathrm{Z}$ & 111 b Y (74) & 15 \\
\hline Pyraflufen-ethyl/2,4-D & 77 b Z & 89 b Y (73) & 11 \\
\hline 2,4-D ester & $24 \mathrm{ab} \mathrm{Z}$ & 48 b Z (75) & 9 \\
\hline Halauxifen-methyl $^{\mathrm{c}}$ & 13 a Z & $18 \mathrm{ab} Z(82)^{* *}$ & 3 \\
\hline Saflufenacil ${ }^{\mathrm{b}}$ & $27 \mathrm{ab} \mathrm{Z}$ & $19 \mathrm{ab} Z(61)^{* *}$ & 8 \\
\hline Dicamba & 4 a Z & 3 a $Z(85)^{* *}$ & 1 \\
\hline $\mathrm{SE}$ & 9 & 8 & \\
\hline
\end{tabular}

Note. Abbreviations: SE, standard error. Means accompanied by different letters in a column (a-c) or row (Z, Y) differ significantly based on Tukey Kramer's LSD $(\mathrm{P}<0.10)$. ** Significant at $\mathrm{P}<0.01 ; *$ significant at $\mathrm{P}<0.10$ based on a t-test conducted for observed versus expected values. ${ }^{a}$ Values in parentheses represent the expected values from Colby's analysis. ${ }^{b}$ Merge, $1 \mathrm{~L} \mathrm{ha}^{-1}$ was added to all treatments with saflufenacil. ${ }^{\mathrm{c}} \mathrm{MSO}, 1 \% \mathrm{v} / \mathrm{v}$ or $0.5 \% \mathrm{v} / \mathrm{v}$ was added to all treatments with halauxifen-methyl and tiafenacil, respectively. 
At 2 WAA, glyphosate plus bromoxynil controlled GR Canada fleabane 52\% (Table 4). When saflufenacil was added to glyphosate plus bromoxynil GR Canada fleabane control improved from 52 to $85 \%$; control was not improved when metribuzin, tiafenacil, pyraflufen-ethyl/2,4-D, 2,4-D ester, halauxifen-methyl or dicamba were added to glyphosate plus bromoxynil. Limited research exists on GR Canada fleabane control using glyphosate plus bromoxynil plus saflufenacil though; previous literature has reported improved GR Canada fleabane control when saflufenacil was added to other herbicide tankmix partners. Hedges et al. (2018) reported when saflufenacil $\left(25 \mathrm{~g}_{\mathrm{ai} \mathrm{h}} \mathrm{a}^{-1}\right)$ was added to glyphosate/dicamba $\left(1800 \mathrm{~g} \mathrm{ae} \mathrm{ha}^{-1}\right)$ GR Canada fleabane control improved from 54 to $97 \%$ at 2 WAA. Glyphosate plus metribuzin, tiafenacil, pyraflufen-ethyl/2,4-D, 2,4-D ester, halauxifen-methyl, saflufenacil or dicamba controlled GR Canada fleabane 43,60,58,47, 58, 84, and 52\%, respectively. When bromoxynil was added to glyphosate plus metribuzin, 2,4-D ester or dicamba, GR Canada fleabane control was improved from 43 to $62 \%, 47$ to $74 \%$, and 52 to $80 \%$, respectively; control was not improved when bromoxynil was added to glyphosate plus tiafenacil, pyraflufen-ethyl/2,4-D, halauxifen-methyl or saflufenacil. Similarly, Westerveld et al. (2021a) reported the addition of bromoxynil $\left(280 \mathrm{~g}\right.$ ai ha $\left.{ }^{-1}\right)$ to glyphosate $\left(900 \mathrm{~g}\right.$ ae ha $\left.{ }^{-1}\right)$ plus metribuzin (400 $\mathrm{g}_{\text {ai }} \mathrm{ha}^{-1}$ ) improved GR Canada fleabane control from 78 to $97 \%$ at 2 WAA. Based on the Colby's equation, glyphosate plus bromoxynil plus tiafenacil, pyraflufen-ethyl/2,4-D or halauxifen-methyl was antagonistic since the observed control was less than the expected control; all other tankmixtures were additive.

At 4 WAA, glyphosate plus bromoxynil provided 58\% GR Canada fleabane control (Table 4). When dicamba was added to glyphosate plus bromoxynil GR Canada fleabane control improved from 58 to $95 \%$; control was not improved from the addition of metribuzin, tiafenacil, pyraflufen-ethyl/2,4-D, 2,4-D ester, halauxifen-methyl or saflufenacil to glyphosate plus bromoxynil. To our knowledge, there is currently no existing research on GR Canada fleabane control with glyphosate plus bromoxynil plus dicamba though; previous research has reported improved GR Canada fleabane control when dicamba was added to other herbicide tankmix partners. Zimmer et al. (2018b) reported the addition of dicamba $\left(280 \mathrm{~g}_{\text {ae ha }}{ }^{-1}\right)$ to glyphosate $\left(560 \mathrm{~g}\right.$ ae ha $\left.{ }^{-1}\right)$ plus 2,4-D (560 $\mathrm{g}$ ae ha ${ }^{1}$ ) applied PP in soybean, improved GR Canada fleabane control from 71 to $95 \%$ at 5 WAA. Glyphosate plus metribuzin, tiafenacil, pyraflufen-ethyl/2,4-D, 2,4-D ester, halauxifen-methyl, saflufenacil or dicamba controlled GR Canada fleabane $45,50,66,77,87,87$, and $87 \%$, respectively. When bromoxynil was added to glyphosate plus metribuzin GR Canada fleabane control improved from 45 to $66 \%$; control was not improved when bromoxynil was added to glyphosate plus tiafenacil, pyraflufen-ethyl/2,4-D, 2,4-D ester, halauxifen-methyl, saflufenacil or dicamba. Similarly, Westerveld et al. (2021a) reported the addition of bromoxynil $\left(280 \mathrm{~g}^{2} \mathrm{ha}^{-1}\right)$ to glyphosate $\left(900 \mathrm{~g}_{\text {ae }} \mathrm{ha}^{-1}\right)$ plus metribuzin $\left(400 \mathrm{~g}_{\text {ai ha }}{ }^{-1}\right)$ improved GR Canada fleabane control from 80 to $98 \%$ at 4 WAA; which is much higher than the $66 \%$ GR Canada fleabane control reported in the present study at 4 WAA. Based on the Colby's equation, the observed control values for bromoxynil plus glyphosate plus pyraflufen-ethyl/2,4-D, 2,4-D ester or halauxifen-methyl were less than the expected control values indicating an antagonistic interaction; all other tankmixtures were additive.

At 8 WAA, glyphosate plus bromoxynil controlled GR Canada fleabane 69\% (Table 4). When dicamba was added to glyphosate plus bromoxynil GR Canada fleabane control improved from 69 to $97 \%$; control was not improved from the addition of metribuzin, tiafenacil, pyraflufen-ethyl/2,4-D, 2,4-D ester, halauxifen-methyl or saflufenacil to glyphosate plus bromoxynil. Previous studies reported improved GR Canada fleabane control when dicamba was added to other herbicide tankmixtures. Budd et al. (2016) reported when dicamba (600 g ae $\left.\mathrm{ha}^{-1}\right)$ was added to glyphosate $\left(900 \mathrm{~g}\right.$ ae ha $\left.\mathrm{h}^{-1}\right)$ plus saflufenacil $\left(25 \mathrm{~g}\right.$ ai ha $\left.\mathrm{a}^{-1}\right)$ applied PP in soybean GR Canada fleabane control improved from 88 to $98 \%$ at 8 WAA. Glyphosate plus metribuzin, tiafenacil, pyraflufen-ethyl/2,4-D, 2,4-D ester, halauxifen-methyl, saflufenacil or dicamba controlled GR Canada fleabane $46,51,68,84,89,87$, and $94 \%$, respectively. When bromoxynil was added to glyphosate plus metribuzin, tiafenacil or pyraflufen-ethyl/2,4-D GR Canada fleabane control improved from 46 to $72 \%, 51$ to $70 \%$, and 68 to $87 \%$, respectively; control was not improved when bromoxynil was added to glyphosate plus 2,4-D ester, halauxifen-methyl, saflufenacil or dicamba. Westerveld et al. (2021a) reported similar results when bromoxynil (280 $\mathrm{g}$ ai ha $\mathrm{ha}^{-1}$ ) was added to glyphosate $\left(900 \mathrm{~g}\right.$ ae ha $\mathrm{ha}^{-1}$ ) plus metribuzin (400 $\mathrm{g}$ ai ha ${ }^{-1}$ ); GR Canada fleabane control improved from 76 to $97 \%$ at 8 WAA, which is much higher than the $72 \%$ GR Canada fleabane control reported in the present study at 8 WAA. Based on the Colby's equation, the observed control for glyphosate plus bromoxynil plus tiafenacil or halauxifen-methyl were less than the expected control demonstrating an antagonistic interaction; in contrast, the observed control for glyphosate plus bromoxynil plus pyraflufen-ethyl/2,4-D was greater than the expected indicating a synergistic interaction. All other tankmixtures were considered additive. Westerveld et al. (2021b) reported synergism when pyraflufen-ethyl/2,4-D (527 g ai

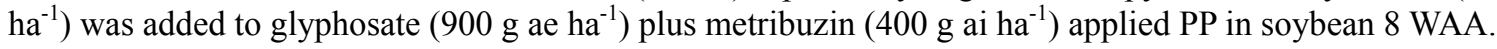




\subsection{Glyphosate-Resistant Canada Fleabane Consistency in Control}

The coefficient of variation (CV) is a standardized measure of the standard deviation to the mean and is useful for investigating data variability (Shechtman, 2013). The CV for each least square mean was used as an indicator to demonstrate the consistency of GR Canada fleabane control (Table 5). When comparing CVs, a lower CV would indicate greater consistency in control (Shechtman, 2013).

Table 5. Glyphosate-resistant Canada fleabane consistency of control 2, 4, and 8 weeks after application (WAA) with bromoxynil-based tankmixes from four field trials conducted in southwestern Ontario, Canada in 2020 and 2021

\begin{tabular}{|c|c|c|}
\hline \multirow{2}{*}{ Bromoxynil } & \multicolumn{2}{|c|}{ Tankmix partners } \\
\hline & None & Bromoxynil \\
\hline Consistency of control 2 WAA & \multicolumn{2}{|c|}{----------- Coefficient of variation --------- } \\
\hline None & - & 99 \\
\hline Metribuzin & 111 & 88 \\
\hline Tiafenacil $^{\mathrm{c}}$ & 90 & 90 \\
\hline Pyraflufen-ethyl/2,4-D & 92 & 82 \\
\hline 2,4-D ester & 105 & 77 \\
\hline Halauxifen-methyl $^{\text {b }}$ & 92 & 79 \\
\hline Saflufenacil $^{\mathrm{a}}$ & 69 & 68 \\
\hline Dicamba & 99 & 82 \\
\hline \multicolumn{3}{|l|}{ Consistency of control 4 WAA } \\
\hline None & - & 78 \\
\hline Metribuzin & 92 & 71 \\
\hline Tiafenacil $^{\mathrm{c}}$ & 86 & 74 \\
\hline Pyraflufen-ethyl/2,4-D & 71 & 62 \\
\hline 2,4-D ester & 63 & 59 \\
\hline Halauxifen-methyl $^{\mathrm{b}}$ & 56 & 56 \\
\hline Saflufenacil $^{\mathrm{a}}$ & 56 & 52 \\
\hline Dicamba & 56 & 50 \\
\hline \multicolumn{3}{|l|}{ Consistency of control 8 WAA } \\
\hline None & - & 68 \\
\hline Metribuzin & 89 & 66 \\
\hline Tiafenacil $^{c}$ & 84 & 67 \\
\hline Pyraflufen-ethyl/2,4-D & 69 & 56 \\
\hline 2,4-D ester & 57 & 57 \\
\hline Halauxifen-methyl $^{\mathrm{b}}$ & 54 & 56 \\
\hline Saflufenacil $^{\mathrm{a}}$ & 55 & 50 \\
\hline Dicamba & 51 & 48 \\
\hline
\end{tabular}

Note. ${ }^{\mathrm{a}}$ Merge, $1 \mathrm{~L} \mathrm{ha}^{-1}$ was included in all treatments with saflufenacil. ${ }^{\mathrm{b}} \mathrm{MSO}, 1 \% \mathrm{v} / \mathrm{v}$ was included in all treatments with halauxifen-methyl and tiafenacil.

At 2, 4, and 8 WAA, the addition of metribuzin, tiafenacil, pyraflufen-ethyl/2,4-D, 2,4-D ester, halauxifen-methyl, saflufenacil or dicamba to glyphosate plus bromoxynil improved the consistency of GR Canada fleabane control, as indicated by lower CVs compared to the CV of glyphosate plus bromoxynil. When bromoxynil was added to glyphosate plus metribuzin, tiafenacil, pyraflufen-ethyl/2,4-D, 2,4-D ester, halauxifen-methyl, saflufenacil or dicamba the consistency of GR Canada fleabane control was improved as indicated by lower CVs except for glyphosate plus bromoxynil plus halauxifen-methyl at 4 and 8 WAA, which did not improve the consistency of control. It has been suggested that a third herbicide into the tankmix improves the consistency of GR Canada fleabane control (Mellendorf et al., 2013). Soltani et al. (2020b) reported improved consistency of GR Canada fleabane control when a third herbicide, such as metribuzin $\left(400 \mathrm{~g}^{-1 \mathrm{ha}^{-1}}\right)$,

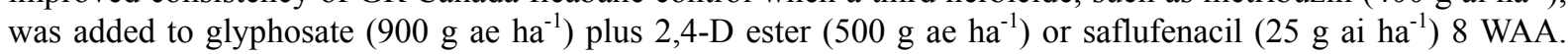
Budd et al. (2016) observed an improvement in the consistency of GR Canada fleabane control when metribuzin

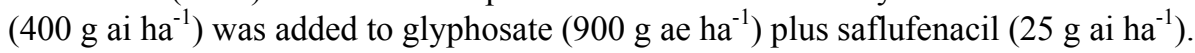




\subsection{Glyphosate-Resistant Canada Fleabane Density and Biomass}

There was a significant interaction between Factor One (control and bromoxynil) and Factor Two (control, metribuzin, tiafenacil, pyraflufen-ethyl/2,4-D, 2,4-D ester, halauxifen-methyl, saflufenacil, and dicamba) for GR Canada fleabane density and biomass $(\mathrm{P}=0.10)$, so the simple effects are presented (Table 4).

There were relatively high populations of GR Canada fleabane at the study sites, with an average of 164 GR Canada fleabane plants per $\mathrm{m}^{-2}$ across the four sites at 8 WAA. At 8 WAA, glyphosate plus bromoxynil reduced GR Canada fleabane density $82 \%$. GR Canada fleabane density was not reduced when metribuzin, tiafenacil, pyraflufen-ethyl/2,4-D, 2,4-D ester, halauxifen-methyl, saflufenacil or dicamba were added to glyphosate plus bromoxynil. Glyphosate plus metribuzin, pyraflufen-ethyl/2,4-D, 2,4-D ester, halauxifen-methyl, saflufenacil or dicamba reduced GR Canada fleabane density $78,68,82,88,90$, and $85 \%$, respectively; density was not reduced with glyphosate plus tiafenacil. Similar reductions in GR Canada fleabane density have been reported in previous research (Budd et al., 2016; Eubank et al., 2008; Soltani et al., 2020a; Westerveld et al., 2021c; Zimmer et al., 2018b). When bromoxynil was added to glyphosate plus metribuzin, tiafenacil or pyraflufen-ethyl/2,4-D GR Canada fleabane density was reduced 7,22 , and $20 \%$, respectively; density was not reduced when bromoxynil was added to glyphosate plus 2,4-D ester, halauxifen-methyl, saflufenacil or dicamba. In contrast, Westerveld et al. (2021a) reported no reduction in GR Canada fleabane density when bromoxynil ( $\left.280 \mathrm{~g}^{2} \mathrm{a} \mathrm{ha}^{-1}\right)$ was added to glyphosate $\left(900 \mathrm{~g} \mathrm{ae} \mathrm{ha}^{-1}\right)$ plus metribuzin $\left(400 \mathrm{~g}\right.$ ai ha $\left.{ }^{-1}\right) 8$ WAA. Based on the Colby's equation, the observed density for glyphosate plus bromoxynil plus metribuzin, pyraflufen-ethyl/2,4-D, 2,4-D ester, halauxifen-methyl, saflufenacil or dicamba were less than the expected indicating synergistic interactions; the tankmix of bromoxynil plus glyphosate plus tiafenacil was additive.

At 8 WAA, glyphosate plus bromoxynil reduced GR Canada fleabane biomass $43 \%$. When dicamba was added to glyphosate plus bromoxynil GR Canada fleabane biomass was reduced by $97 \%$; there was no reduction in biomass when metribuzin, tiafenacil, pyraflufen-ethyl/2,4-D, 2,4-D ester, halauxifen-methyl or saflufenacil was added to glyphosate plus bromoxynil. There is minimal research on the efficacy of glyphosate plus bromoxynil plus dicamba though, the addition of dicamba $\left(600 \mathrm{~g}\right.$ ae ha $\left.{ }^{-1}\right)$ to other herbicides such as glyphosate $(900 \mathrm{~g}$ ae $\mathrm{ha}^{-1}$ ) plus saflufenacil $\left(25 \mathrm{~g}\right.$ ai ha ${ }^{-1}$ ) reduced GR Canada fleabane biomass up to $100 \%$ (Byker et al. 2013a) and 86\% (Budd et al., 2016), respectively. Glyphosate plus halauxifen-methyl or dicamba reduced GR Canada fleabane biomass 92 and $97 \%$, respectively; biomass was not reduced with glyphosate plus metribuzin, tiafenacil, pyraflufen-ethyl/2,4-D, 2,4-D ester or saflufenacil. Similar reductions in GR Canada fleabane biomass have been reported in past research (Budd et al., 2016; Byker et al., 2013a; Quinn et al., 2021). When bromoxynil was added to glyphosate plus metribuzin GR Canada fleabane biomass was reduced by $18 \%$; interestingly, there was no benefit of adding bromoxynil to glyphosate plus tiafenacil, pyraflufen-ethyl/2,4-D, 2,4-D ester, halauxifen-methyl, saflufenacil or dicamba in respect to Canada fleabane biomass. Westerveld et al. (2021a) reported a $30 \%$ reduction in GR Canada fleabane biomass when bromoxynil $\left(280 \mathrm{~g}\right.$ ai ha $\left.{ }^{-1}\right)$ was added to glyphosate $\left(900 \mathrm{~g}_{\text {ae ha }}{ }^{-1}\right)$ plus metribuzin $\left(400 \mathrm{~g}_{\text {ai ha }}{ }^{-1}\right) 8$ WAA. Based on the Colby's equation, the observed biomass values for bromoxynil plus glyphosate plus halauxifen-methyl, saflufenacil or dicamba were less than the expected indicating a synergistic interaction; all other tankmixtures were considered additive.

\subsection{Soybean Yield}

There was no interaction between Factor One (control, bromoxynil) and Factor Two (control, metribuzin, tiafenacil, pyraflufen-ethyl/2,4-D, 2,4-D ester, halauxifen-methyl, saflufenacil, and dicamba) for GR Canada fleabane interference on soybean yield, so the main effects are presented (Table 6). All herbicide treatments resulted in similar soybean yields. Zimmer et al. (2018a) reported similar soybean yields compared to this study. In contrast, Budd et al. (2016) reported a 69\% soybean yield reduction from GR Canada fleabane interference. 
Table 6. Main effects and interaction for glyphosate-resistant Canada fleabane control 2, 4, and 8 weeks after application (WAA), density, biomass, and soybean yield with bromoxynil-based tankmixes from four field trials conducted in southwestern Ontario, Canada in 2020 and 2021

\begin{tabular}{|c|c|c|c|c|c|c|c|}
\hline \multirow{2}{*}{ Main effects } & \multirow{2}{*}{ Rate (g ai/ae ha $\left.{ }^{-1}\right)$} & \multicolumn{3}{|c|}{ Canada fleabane control } & \multirow{2}{*}{ Density $^{\mathrm{a}}$} & \multirow{2}{*}{ Biomass $^{\mathrm{a}}$} & \multirow{2}{*}{ Soybean yield } \\
\hline & & 2 WAA & 4 WAA & 8 WAA & & & \\
\hline & & \multicolumn{3}{|c|}{------------- \% -------------- } & Plants $\mathrm{m}^{-2}$ & $\mathrm{~g} \mathrm{~m}^{-2}$ & $\mathrm{t} \mathrm{ha}^{-1}$ \\
\hline Bromoxynil & & NS & $*$ & $*$ & $*$ & NS & NS \\
\hline None & - & 0 & 0 & 0 & 47 & 60 & 2.05 \\
\hline Bromoxynil & 280 & 67 & 76 & 79 & 20 & 45 & 2.03 \\
\hline $\mathrm{SE}$ & & 2 & 2 & 2 & 4 & 6 & 0.051 \\
\hline Tankmix partners & & $* *$ & $* *$ & $* *$ & $* *$ & $* *$ & NS \\
\hline None & - & 0 & 0 & 0 & 89 & 125 & 2.04 \\
\hline Metribuzin & 400 & 53 & 55 & 58 & 20 & 151 & 1.84 \\
\hline Tiafenacil $^{\mathrm{c}}$ & 25 & 57 & 57 & 60 & 27 & 107 & 1.85 \\
\hline Pyraflufen-ethyl/2,4-D & 532 & 61 & 69 & 73 & 31 & 85 & 2.09 \\
\hline 2,4 -D ester & 528 & 58 & 76 & 81 & 12 & 33 & 2.14 \\
\hline Halauxifen-methyl $^{\mathrm{c}}$ & 5 & 63 & 84 & 85 & 11 & 15 & 2.28 \\
\hline Saflufenacil $^{\mathrm{b}}$ & 25 & 79 & 86 & 87 & 6 & 22 & 2.03 \\
\hline Dicamba & 600 & 64 & 89 & 94 & 10 & 3 & 2.32 \\
\hline $\mathrm{SE}$ & & 2 & 2 & 2 & 4 & 6 & 0.051 \\
\hline Bromoxynil $\times$ Tankmix partner & & $* *$ & $* *$ & $* *$ & $* *$ & $*$ & NS \\
\hline
\end{tabular}

Note. Abbreviations: SE, standard error.

**Significant at $\mathrm{P}<0.01$; * significant at $\mathrm{P}<0.10$; NS, non-significant. ${ }^{a}$ Density and biomass were collected 8 WAA. ${ }^{\mathrm{b}}$ Merge, $1 \mathrm{~L} \mathrm{ha}^{-1}$ was added to all treatments with saflufenacil. ${ }^{\mathrm{c}} \mathrm{MSO}, 1 \% \mathrm{v} / \mathrm{v}$ or $0.5 \% \mathrm{v} / \mathrm{v}$ was added to all treatments with halauxifen-methyl and tiafenacil, respectively.

In conclusion, limited research exists on GR Canada fleabane control with bromoxynil-based tankmixtures applied PP to soybean. Glyphosate plus bromoxynil plus metribuzin, tiafenacil, pyraflufen-ethyl/2,4-D, 2,4-D ester, halauxifen-methyl, saflufenacil or dicamba caused $\leq 10 \%$ visible soybean injury. At 2 WAA, when saflufenacil was added to glyphosate plus bromoxynil GR Canada fleabane control improved from 52 to $85 \%$. At 4 WAA, when dicamba was added to glyphosate plus bromoxynil GR Canada fleabane control improved from 58 to $95 \%$. At 8 WAA, when dicamba was added to glyphosate plus bromoxynil GR Canada fleabane control improved from 69 to $97 \%$. At 2 WAA, the interaction between glyphosate plus bromoxynil plus tiafenacil, pyraflufen-ethyl/2,4-D or halauxifen-methyl was antagonistic. At 4 WAA, the interaction between glyphosate plus bromoxynil plus pyraflufen-ethyl/2,4-D, 2,4-D ester or halauxifen-methyl was antagonistic. At 8 WAA, the interaction between glyphosate plus bromoxynil plus tiafenacil or halauxifen-methyl was antagonistic; while the interaction between glyphosate plus bromoxynil plus pyraflufen-ethyl/2,4-D was synergistic. The interactions for the other tankmixtures were additive. In conclusion, the addition of saflufenacil to glyphosate plus bromoxynil at 2 WAA and dicamba to glyphosate plus bromoxynil at 4 and 8 WAA improves the level and consistency of GR Canada fleabane control applied PP to soybean.

\section{References}

Andersen, R. N., Behrens, R., Warnes, D. D., \& and Nelson, W. W. (1973). Bromoxynil for control of common cocklebur and wild common sunflower in soybeans. Weed Sci., 21,103-106. https://doi.org/10.1017/ S0043174500031830

Bhowmik, P. C., \& Bekech, M. M. (1993). Horseweed (Conyza canadensis) seed production, emergence, and distribution in no-tillage and conventional-tillage corn (Zea mays). Agronomy J., Trends in Agricultural Sci., $1,67-71$.

Bruce, J. A., \& Kells, J. J. (1990). Horseweed (Conyza canadensis) control in no-tillage soybeans (Glycine max) with preplant and preemergence herbicides. Weed Technol., 4, 642-647. https://doi.org/10.1017/ S0890037X00026130

Boydston, R. A., \& Al-Khatib, K. (1993). Efficacy, site of uptake and retention of bromoxynil in common lambsquarters with conventional and sprinkler application. Weed Sci., 41, 166-17. https://doi.org/10.1017/ S0043174500076013 
Budd, C. M., Soltani, N., Robinson, D. E., Hooker, D. C., Miller, R. T., \& Sikkema, P. H. (2016). Control of glyphosate resistant Canada fleabane with saflufenacil plus tankmix partners in soybean. Canadian J. of Plant Sci., 96(6), 989-994. https://doi.org/10.1139/cjps-2015-0332

Byker, H. P., Soltani, N., Robinson, D. E., Tardif, F. J., Lawton, M. B., \& Sikkema, P. H. (2013a). Control of glyphosate-resistant horseweed (Conyza canadensis) with dicamba applied preplant and postemergence in dicamba-resistant soybean. Weed Technol., 27, 492-496. https://doi.org/10.1614/WT-D-13-00023.1

Byker, H. P., Soltani, N., Robinson, D. E., Tardif, F. J., Lawton, M. B., \& Sikkema, P. H. (2013b). Glyphosate-resistant Canada fleabane [Conyza canadensis (L). Cronq.]: dose response to glyphosate and control with post-emergence herbicides in soybean in Ontario. Canadian J. of Plant Sci., 93, 1187-1193. https://doi.org/10.4141/cjps2013-067

Canadian Weed Science Society. (2018). Description of 0-100 rating scale for herbicide efficacy and crop phytotoxicity. Retrieved March 29, 2021, from https://weedscience.ca/cwss-visual-ratings-scale

Cici, S. Z. H., \& Van Acker, R. C. (2009). A review of the recruitment biology of winter annual weed in Canada. Canadian J. of Plant Sci., 89, 575-589. https://doi.org/10.4141/CJPS08131

Colby, S. R. (1967). Calculating synergistic and antagonistic responses of herbicide combinations. Weeds, 15, 20-22. https://doi.org/10.2307/4041058

Davis, V. M., Kruger, G. R., Stachler, J. M., Loux, M. M., \& Johnson, W. G. (2009). Growth and seed production of horseweed (Conyza canadensis) populations resistant to glyphosate, ALS-inhibiting, and multiple (glyphosate + ALS-inhibiting) herbicides. Weed Sci., 57, 494-504. https://doi.org/10.1614/WS-09-024.1

Eubank, T. W., Poston, D. H., Nandula, V. K., Koger, C. H., Shaw, D. R., \& Reynolds, D. B. (2008). Glyphosate-resistant horseweed (Conyza canadensis) control using glyphosate-, paraquat-, and glufosinate-based herbicide programs. Weed Technol., 22, 16-21. https://doi.org/10.1614/WT-07-038.1

Fedtke, C., \& Duke, S. O. (2005). Herbicides. In B. Hock \& E. F. Elstner (Eds.), Plant Toxicology (pp. 247-330). New York: Marcel Dekker.

Heap, I. (2020). Weeds resistant to EPSP synthase inhibitors (G/9). Retrieved October 23, 2020, from http://www.weedscience.org/Pages/MOA.aspx?MOAID=12

Hedges, B. K., Soltani, N., Robinson, D. E., Hooker, D. C., \& Sikkema, P. H. (2018). Control of glyphosate-resistant Canada fleabane in Ontario with multiple effective modes-of-action in glyphosate/dicamba-resistant soybean. Canadian J. of Plant Sci., 99(1), 78-83. https://doi.org/10.1139/ cjps-2018-0067

Mahoney, K. J., McNaughton, K. E., \& Sikkema, P. H. (2016). Control of glyphosate-resistant horseweed in winter wheat with pyrasulfotole premixed with bromoxynil. Weed Technol., 30, 291-296. https://doi.org/ 10.1614/WT-D-15-00046.1

Mahoney, K. J., Shropshire, C., \& Sikkema, P. H. (2017). Post-emergence herbicides for control of glyphosateresistant Canada fleabane in corn. Canadian J. of Plant Sci., 97, 206-209. https://doi.org/10.1139/ CJPS-2016-0221

Main, C. L., Steckel, L. E., Hayes, R. M., \& Mueller, T. C. (2006). Biotic and abiotic factors influence horseweed emergence. Weed Sci., 54, 1101-1105. https://doi.org/10.1614/WS-06-026R1.1

Mellendorf, T. G., Young, J. M., Matthews, J. L., \& Young, B. G. (2013). Influence of plant height and glyphosate on saflufenacil efficacy on glyphosate-resistant horseweed (Conyza canadensis). Weed Technol., 27, 463-467. https://doi.org/10.1614/WT-D-13-00004.1

Metzger, B. A., Soltani, N., Raeder, A. J., Hooker, D. C., Robinson, D. E., \& Sikkema, P. H. (2019). Multiple herbicide-resistant horseweed (Conyza canadensis) dose response to tolpyralate and tolpyralate plus atrazine and comparison to industry standard herbicides in corn. Weed Technol., 33, 366-373. https://doi.org/10.1017/ wet. 2019.20

Nandula, V. K., Eubank, T. W., Poston, D. H., Koger, C. H., \& Reddy, K. H. (2006). Factors affecting germination of horseweed (Conyza canadensis). Weed Sci., 54, 898-902. https://doi.org/10.1614/ WS-06-006R2.1

Quinn, J., Ashigh, J., Soltani, N., Hooker, D. C., Robinson, D. E., \& Sikkema, P. H. (2021). Control of glyphosate-resistant horseweed and giant ragweed in soybean with halauxifen-methyl applied preplant. Weed Technol., 35, 234-329. https://doi.org/10.1017/wet.2020.118 
Shaner, D. L. (2014). Dicamba herbicide handbook (10th ed., pp. 79-141). Lawrence, KS: Weed Science Society of America.

Shechtman, O. (2013). The coefficient of variation as an index of measurement reliability, in: social determinants of health in non-communicable diseases (pp. 39-49). Social Determinants of Health in Non-communicable Diseases.

Shields, E. J., Dauer, J. T., VanGessel, M. J., \& Neumann, G. (2006). Horseweed (Conyza canadensis) seed collected in the planetary boundary layer. Weed Sci., 54, 1063-1067. https://doi.org/10.1614/WS-06-097R1.1

Soltani, N., Shropshire, C., \& Sikkema, P. H. (2020a). Control of glyphosate-resistant marestail in identity-preserved or glyphosate-resistant and glyphosate/dicamba-resistant soybean with preplant herbicides. Amer. J. of Plant Sci., 11, 851-860. https://doi.org/10.4236/ajps.2020.116061

Soltani, N., Shropshire, C., \& Sikkema, P. H. (2020b). Glyphosate-resistant Canada fleabane control with three-way herbicide tankmixes in soybean. Amer. J. of Plant Sci., 11, 1478-1486. https://doi.org/ 10.4236/ajps.2020.119107

United States Environmental Protection Agency. (1998). Registration eligibility decision (RED) bromoxynil (EPA 738-R-98-013). Washington, DC: U.S. Environmental Protection Agency.

VanGessel, M. J. (2001). Glyphosate-resistant horseweed from Delaware. Weed Sci., 49, 703-705. https://doi.org/ 10.1614/0043-1745(2001)049[0703:RPRHFD]2.0.CO;2

Wax, L. M., Bernard, R., \& Hayes, R. (1974). Response of soybean cultivars to bentazon, bromoxynil, chloroxuron, and 2,4-DB. Weed Sci., 22(1), 35-41. https://doi.org/10.1017/S004317450003647X

Weaver, S. E. (2001). The biology of Canadian weeds. 115. Conyza canadensis. Canadian J. of Plant Sci., 81, 867-875. https://doi.org/10.4141/P00-196

Westerveld, D. B., Soltani, N., Hooker, D. C., Robinson, D. E., \& Sikkema, P. H. (2021a). Biologically-effective-dose of bromoxynil, applied alone and mixed with metribuzin, for the control of glyphosate-resistant horseweed in soybean. Weed Technol., 1-22. https://doi.org/10.1017/wet.2021.12

Westerveld, D. B., Soltani, N., Hooker, D. C., Robinson, D. E., \& Sikkema, P. H. (2021b). Biologically effective dose of pyraflufen-ethyl/2,4-D, applied preplant alone or mixed with metribuzin on glyphosate-resistant horseweed in soybean. Weed Technol., 1-6. https://doi.org/10.1017/wet.2021.46

Westerveld, D. B., Soltani, N., Hooker, D. C., Robinson, D. E., \& Sikkema, P. H. (2021c). Efficacy of tiafenacil applied preplant alone or mixed with metribuzin for glyphosate-resistant horseweed control in soybean. Weed Technol., 1-7. https://doi.org/10.1017/wet.2021.39

Zimmer, M., Young, B. G., \& Johnson, W. G. (2018a). Herbicide programs utilizing halauxifen-methyl for glyphosate resistant horseweed (Conyza canadensis) control in soybean. Weed Technol., 32, 659-664. https://doi.org/10.1017/wet.2018.60

Zimmer, M., Young, B. G., \& Johnson, W. G. (2018b). Weed control with halauxifen-methyl applied alone and in mixtures with 2,4-D, dicamba, and glyphosate. Weed Technol., 32, 597-602. https://doi.org/10.1017/ wet.2018.48

Bayer CropScience Inc. (2019). Pardner Label. Retrieved August 4, 2020, from https://www.cropscience.bayer. $\mathrm{ca} /$ //media/Bayer-CropScience/Country-Canada-Internet/Products/Pardner/Pardner-Label.ashx?la=en\&hash $=$ BD9F5BC6E78F5F 7E68739765E4E66D9B52B10D6B

\section{Copyrights}

Copyright for this article is retained by the author(s), with first publication rights granted to the journal.

This is an open-access article distributed under the terms and conditions of the Creative Commons Attribution license (http://creativecommons.org/licenses/by/4.0/). 